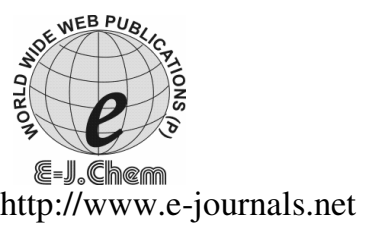

\title{
Synthesis, Characterization and Chelating Properties of Benzoxazolidin-2-one/ 4 - aminosalicylic Acid Clubbed Molecule. Part - I
}

\author{
G. J. PATEL ${ }^{*}$, M. V. HATHI ${ }^{1}$, and S.V. PATEL ${ }^{2}$ \\ Home Science Department, Mahila Arts \& Commerce College \\ Dhansura, Dist. Sabarkantha (Gujarat) India. Pin - 383310 \\ ${ }^{1}$ Principal, Commerce \& Science College \\ Palanpur, Dist. Banaskantha (Gujarat) India \\ ${ }^{2}$ Chemistry Department, Sir P. T. Science College \\ Modasa, Dist. Sabarkantha, (GUJARAT) India. Pin-383315
}

Received 22 July 2006; Accepted 22 August 2006

\begin{abstract}
Aminomethylation of benzoxazolidin-2-one was carried out by treating benzoxazolidin-2-one with formaldehyde and 4 - aminosalicylic acid. The resultant compound was designated as 3-(4-carboxy-3 - hydroxyphenyl aminomethyl) benzoxazolidin-2-one (CHPA-BOX) The transition metal complexes of $\mathrm{Cu}^{2+} \mathrm{Co}^{2+} \mathrm{Ni}^{2+}, \mathrm{Mn}^{2+}, \mathrm{Zn}^{2+}, \mathrm{UO}^{2+}$ and $\mathrm{Fe}^{3+}$ of CHPA-BOX have been prepared. Elemental analyses, spectral studies, magnetic moment determination, molar conductivity measurement and microbial activity of CHPA$\mathrm{BOX}$ and its metal complexes were carried out.
\end{abstract}

Keywords: Benzoxazolidin-2 -one, 4-aminosalicylic acid, metal complexes, spectral studies, magnetic moment, antibacterial and antifungal activity.

\section{Introduction}

Benzoxazolidin-2-one is found as an important heterocyclic compound. It is versatile compound and finds many derivatives for pharmaceutical applications ${ }^{1-5}$. Its amino methylation (i.e. Mannich reaction) has been carried out successfully by Indian scientists ${ }^{6}$. The area in which the amiono methylation of benzaxozolidin -2 - one by using aromatic amine having metal gripping group (i.e. ligand) has not been developed. Hence it was thought to undertake such work. With this view, the present communication describe the 
synthesis and characterization of benzaxoazolidin-2-one 4-amino salicylic acid clubbed molecule and its metal complexes. The work is illustrated in Scheme -1.
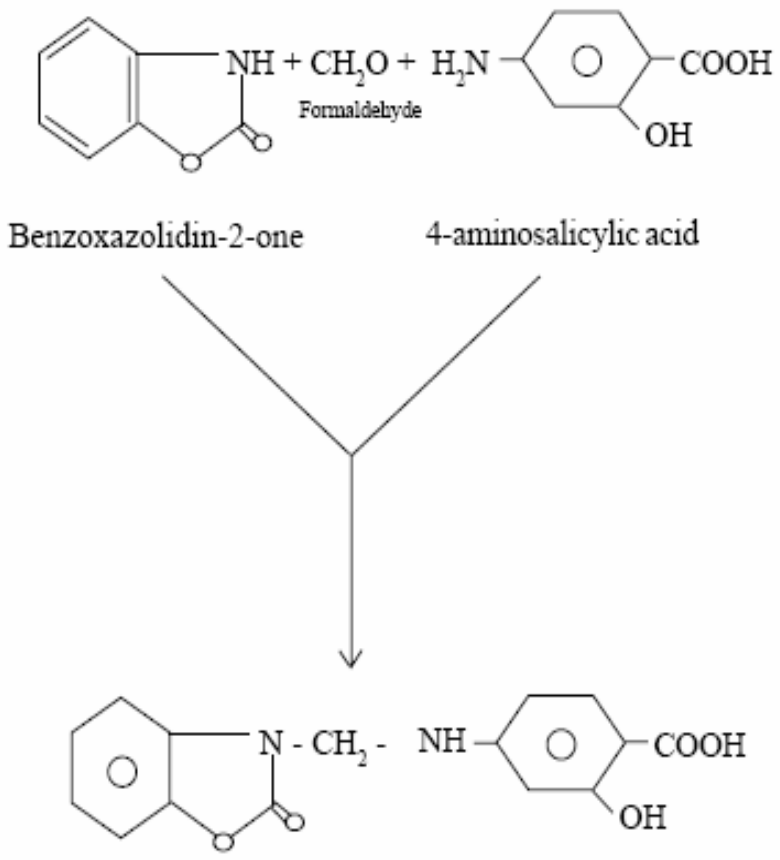

3-(4- carboxy - 3 -hydroxy phenyl amino methyl) benzoxazolidin - 2-one (CHPA-BOX)

Metal Salt

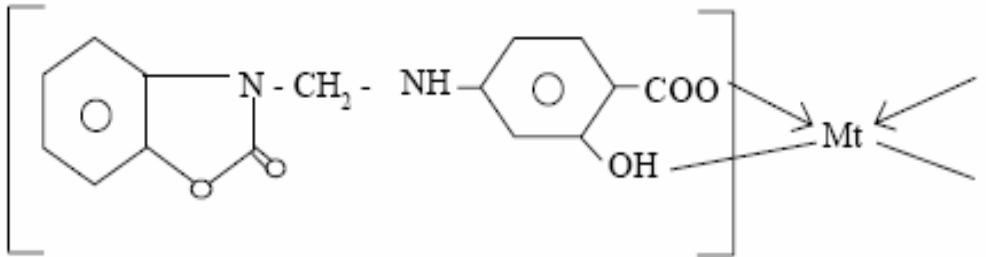

CHPA-BOX-Metal Complexes

Where $\mathrm{Mt}: \mathrm{Cu}^{2+}, \mathrm{Ni}^{2+}, \mathrm{Zn}^{2+}, \mathrm{Mn}^{2+}, \mathrm{Co}^{2+}, \mathrm{Fe}^{3+}$

\section{Scheme-1}




\section{Experimental}

Materials

Benzoxazolidin-2-one was prepared by method reported in literature ${ }^{7}$ - -Amino salicylicacid (PAS) (i.e. 4-Aminosalicylic acid) was obtained from local dealer. All other chemicals used were of analytical grade.

\section{Synthesis of 1-(4-carboxy 3-hydroxy phenyl aminomethyl benzoxazolidin-2-one Formation CHAP - BOX}

A mixture of $(3 \mathrm{H})$ - benzoxazolidin-2-one (BOX) (0.02 mole), formaldehyde $(0.02$ mole $)$ and 4-aminosalicylic acid (PAS) $(0.02$ mole) in ethenol $(70 \mathrm{ml})$ was heated under refluxed for $4 \mathrm{~h}$. Subsequently ethenol was distilled off and the lump mass obtained. It was triturated with petroleum ether $\left(40-60^{\circ} \mathrm{C}\right)$. The solid designated as CHAP-BOX was isolated and dried in air. Yield was $68 \%$. It's m.p. was $173-174^{\circ} \mathrm{C}$ (uncorrected).

\section{Elemental Analysis}

$\mathrm{C}_{15} \mathrm{H}_{12} \mathrm{O}_{5} \mathrm{~N}_{2,}$ (300)

$\begin{array}{rlll} & \mathrm{C} \% & \mathrm{H} \% & \mathrm{~N} \% \\ \text { Calculated : } & 60.00 & 4.00 & 9.33 \\ \text { Found : } & 59.8 & 3.9 & 9.2\end{array}$

Acid Value Theoretical : $186.6 \mathrm{mg} \mathrm{KOH} / 1 \mathrm{~g}$. Sample.

Found : $184 \mathrm{KOH} / \mathrm{g}$ Sample.

IR Features $\quad 1480-1520 \mathrm{~cm}^{-1}$. Benzoxazolin-2-one $3030,1500,1600 \mathrm{~cm}^{-1}$ Aromatic.

$1680 \mathrm{~cm}^{-1} \quad v \mathrm{CO}$ of $\mathrm{COOH}$

$3200-3600 \mathrm{~cm}^{-1} \mathrm{OH}$

$3400 \mathrm{~cm}^{-1} \quad$ Sec. NH

NMR $\quad 7.2-7.6 \mathrm{ppm} \quad$ Multiplet aromatic

(DMSO) $\quad 2.56 \mathrm{ppm}(2 \mathrm{H}) \quad$ Singlet $\mathrm{CH}_{2}$

$10.1 \mathrm{ppm}(1 \mathrm{H}) \quad$ Singlet $(\mathrm{COOH})$

$3.8 \mathrm{ppm}(1 \mathrm{H}) \quad$ Singlet $(\mathrm{OH})$

\section{Synthesis of metal complexes of CHAP - BOX}

Formation of CHAP-BOX metal complexes

The $\mathrm{Cu}^{2+}, \mathrm{Co}^{2+}, \mathrm{Ni}^{2+}, \mathrm{Mn}^{2+}, \mathrm{Zn}^{2+}, \mathrm{UO}^{2+}$ and $\mathrm{Fe}^{3+}$ metal ion complexes of CHAP-BOX have been prepared in a similar manner. The procedure is as follow.

To a solution of CHAP-BOX (0.1 mole) in ethanol-acetone(1:1) mixture $(150 \mathrm{ml})$, $0.1 \mathrm{~N} \mathrm{KOH}$ solution was added drop wise with stirring. The pasty precipitates were obtained at neutral $p \mathrm{H}$. These were dissolved by addition of water up to clear solution. It was diluted to $250 \mathrm{ml}$. by water and was known as stock solution $25 \mathrm{ml}$ of the stock solution (which contains 0.01 mole CHAP-BOX) was added drop wise to the solution of metal salt (0.005 mole for divalent metal ions and 0.0033 mole for $\mathrm{Fe}^{3+}$ ion) in water at room temperature. Sodium acetate or ammonia was added up to complete precipitation. The precipitates were digested on water bath at $80^{\circ} \mathrm{C}$ for $2 \mathrm{~h}$. The digested precipitates of complex were filtered washed with water and air dried. It was amorphous powder. Yield was almost quantitative. The details are given in Table-1. 


\section{Measurements}

The elemental analysis for $\mathrm{C}, \mathrm{H}$ and $\mathrm{N}$ were carried out on elemental analyzer. IR spectra of CHAPBOX and its metal complexes were scanned on a Nicolet 760FTIR spectrophotometer in $\mathrm{KBr}$. The metal content of the metal chelate were performed by decomposing a weighed amount of each metal complexes followed by EDTA titration as reported in literature ${ }^{8}$. Magnetic susceptibility measurement of all the metal complex was carried out at room temperature by the Gouy method. Mercury tetrathiocynatocobaltate (II) $\mathrm{Hg}\left[\mathrm{CO}(\mathrm{NCS})_{4}\right]$ was used as a calibrant. The diffused reflectance spectra of solid metal complex were recorded on a Backman DK Spectrophotometer with a solid reflectance attachment, $\mathrm{MgO}$ was employed as the reflectance compound. The electrical conductivity of all the complexes was measure in $\mathrm{CH}_{3} \mathrm{CN}$ at $10^{-3} \mathrm{M}$ concentration.

\section{Antifungal activity}

The fungicidal activity of all the compounds were studied at $1000 \mathrm{ppm}$ concentration in vitro. Plant pathogenic organisms listed in Table -3 were used. The antifungal activity of all the samples were measured by cup plate method ${ }^{9}$. Each of the plant pathogenic strains on a potato dextrose agar (PDA) medium. Such a PDA medium contained potato $200 \mathrm{gms}$, dextrose $20 \mathrm{gms}$, agar 20gms, and water 1 litre. 5 days old culter were employed. The compounds to be tested were suspended $(1000 \mathrm{ppm})$ in a PDA medium and autoclaved at $120^{\circ} \mathrm{C}$ for $15 \mathrm{~min}$. at $15 \mathrm{~atm}$ pressure. These medium were poured into sterile petri plate and the organisms were inoculated after cooling the Petri plated. The percentage inhabitation for fungi was calculated after 5 days using the formula given below.

$$
\text { Percentage of Inhibition }=\frac{100(\mathrm{X}-\mathrm{Y})}{\mathrm{X}}
$$

Where, $\mathrm{X}$ : Area of colony in control plate

$\mathrm{Y}$ : Area of colony in test plate

The fungicidal activity all compounds are shown in Table -3

\section{Results and Discussion}

The parent ligand CHAP-BOX was an amorphous yellow powered, soluble in various solvents like dioxane, DMSO and DMF. The results of elemental analysis of the ligands are reported in Table-1. They are consistant with the predicted structure as shown in Scheme-I the ligand was synthesized as shown in the Scheme-1.

Examination of IR spectrum (not shown) of CHAP-BOX reveals that a broad band of phenolic hydroxyl stretching is observed at $3200-3600 \mathrm{~cm}^{-1}$ as well as additional absorption bands at 3030, 1500 and 1600 are characteristics of the salicylic acid ${ }^{10,11}$ The strong bands at 1680 for $\mathrm{C}=\mathrm{O}$ and band at 3400 for sec. NH. The NMR data (shown in experimental part) also confirm the structure of CHAP-BOX.

The Metal complex of CHAP-BOX with the metal ions $\mathrm{Cu}^{2+}, \mathrm{Co}^{2+}, \mathrm{Ni}^{2+}, \mathrm{Mn}^{2+}, \mathrm{Zn}^{2+}, \mathrm{Fe}^{3+}$, $\mathrm{UO}_{2}{ }^{2+}$ vary in colours. On the basis of the proposed structure as shown in scheme-1, the molecular formula of the CHAP-BOX ligand is $\mathrm{C}_{15} \mathrm{H}_{12} \mathrm{O}_{3} \mathrm{~N}_{2}$ Which upon complexion coordinates with one central metal atom at four coordination sites and with two water molecules. Therefore the general molecular formula of the resulting metal complex is $\left[\mathrm{C}_{15} \mathrm{H}_{11} \mathrm{O}_{5} \mathrm{~N}_{2}\right]_{2} \mathrm{M} \cdot 2 \mathrm{H}_{2} \mathrm{O}$ for divalent metal ions. This has been confirmed by results of elemental analysis of all the seven metal chelates and their parent ligand. The data of elemental analysis reported in Table- 1 are in arrangement with the calculated values of $\mathrm{C}, \mathrm{H}$ and $\mathrm{N}$ based on the above mentioned molecular formula of parent ligand as well as metal complex. The electrical conductivity (Table-1) of these complexes in acetonitrile indicate that the complexes are essentially non electrolytes. 
Table 1. Analytical Data of the Metal Chelates of $\mathrm{HL}_{1}$ (i.e.Q CHPA - BOX)

\begin{tabular}{|c|c|c|c|c|c|c|c|c|c|c|c|}
\hline \multirow{3}{*}{ Compound } & \multirow{3}{*}{ Empirical Formula } & \multirow{3}{*}{$\begin{array}{l}\text { Mol. } \\
\text { Cal. } \\
\text { Gm/mole }\end{array}$} & \multirow{3}{*}{$\begin{array}{l}\text { Yield } \\
(\%)\end{array}$} & \multicolumn{8}{|c|}{ Elemental Analysis } \\
\hline & & & & \multicolumn{2}{|l|}{$\mathrm{O} \%$} & \multicolumn{2}{|l|}{$\mathrm{H} \%$} & \multicolumn{2}{|l|}{$\mathrm{N} \%$} & \multicolumn{2}{|l|}{$\mathrm{M} \%$} \\
\hline & & & & Cal & Found & Cal. & Found & Cal. & Found & Cal. & Found \\
\hline $\mathrm{HL}_{1}(\mathrm{CHPA}-\mathrm{BOX})$ & $\mathrm{C}_{15} \mathrm{H}_{12} \mathrm{~N}_{2} \mathrm{O}_{5}$ & 300.00 & 59 & 60.00 & 59.90 & 4.00 & 3.90 & 9.33 & 9.02 & - & - \\
\hline$\left[\mathrm{CuL}_{1}\left(\mathrm{H}_{2} \mathrm{O}\right)_{2}\right]$ & $\mathrm{C}_{30} \mathrm{H}_{26} \mathrm{~N}_{4} \mathrm{O}_{12} . \mathrm{Cu}^{2+} 2 \mathrm{H}_{2} \mathrm{O}$ & 697.54 & 54 & 51.60 & 51.50 & 3.72 & 3.60 & 8.02 & 7.90 & 9.10 & 8.90 \\
\hline$\left[\mathrm{CoL}_{1}\left(\mathrm{H}_{2} \mathrm{O}\right)_{2}\right]$ & $\mathrm{C}_{30} \mathrm{H}_{26} \mathrm{~N}_{4} \mathrm{O}_{12} \cdot \mathrm{Co}^{2+} 2 \mathrm{H}_{2} \mathrm{O}$ & 692.93 & 58 & 51.95 & 51.80 & 3.75 & 3.70 & 8.08 & 8.00 & 8.50 & 8.40 \\
\hline$\left[\mathrm{NiL}_{1}\left(\mathrm{H}_{2} \mathrm{O}\right)_{2}\right]$ & $\mathrm{C}_{30} \mathrm{H}_{26} \mathrm{~N}_{4} \mathrm{O}_{12} \cdot \mathrm{Ni}^{2+} 2 \mathrm{H}_{2} \mathrm{O}$ & 692.69 & 52 & 51.97 & 51.80 & 3.75 & 3.68 & 8.08 & 7.90 & 8.47 & 8.40 \\
\hline$\left[\mathrm{MnL}_{1}\left(\mathrm{H}_{2} \mathrm{O}\right)_{2}\right]$ & $\mathrm{C}_{30} \mathrm{H}_{26} \mathrm{~N}_{4} \mathrm{O}_{12} . \mathrm{Mn}^{2+} 2 \mathrm{H}_{2} \mathrm{O}$ & 688.94 & 56 & 52.25 & 52.20 & 3.77 & 3.70 & 8.12 & 8.10 & 7.97 & 7.90 \\
\hline$\left[\mathrm{ZnL}_{1}\left(\mathrm{H}_{2} \mathrm{O}\right)_{2}\right]$ & $\mathrm{C}_{30} \mathrm{H}_{26} \mathrm{~N}_{4} \mathrm{O}_{12} \cdot \mathrm{Zn}^{2+} 2 \mathrm{H}_{2} \mathrm{O}$ & 699.39 & 60 & 51.47 & 51.40 & 3.71 & 3.70 & 8.00 & 7.90 & 9.34 & 9.30 \\
\hline$\left[\mathrm{FeL}_{1}\left(\mathrm{H}_{2} \mathrm{O}\right)_{2}\right]$ & $\mathrm{C}_{45} \mathrm{H}_{39} \mathrm{~N}_{6} \mathrm{O}_{18} . \mathrm{Fe}^{3+} 3 \mathrm{H}_{2} \mathrm{O}$ & $1,006.84$ & 58 & 53.63 & 53.50 & 3.87 & 3.80 & 8.34 & 8.20 & 5.54 & 5.50 \\
\hline
\end{tabular}


Inspection of the IR Spectra (not shown) of metal complexes reveals that all the spectra are identical in all respects. The comparison of IR spectrum of the parent ligand CHAP BOX with that of its each metal complex has revealed certain characteristics differences.

One of the significant difference to be expected between the IR spectrum of the parent ligand and its metal complex is the presence of more broadened bands in the region of $3200-3600 \mathrm{~cm}^{-1}$ for the metal complex as the oxygen of the $\mathrm{O}-\mathrm{H}$ group of the ligands forms a coordination bond with the metal ions. ${ }^{10-12}$. This is explaind by the fact that water molecules might have strongly absorbed to the metal chelates sample during their formation. Another noticeable difference is that the bands due to the $\mathrm{COO}^{-}$anion at $1600 \mathrm{~cm}^{-1}$ in the IR spectrum of the each metal complex. The band at $1400 \mathrm{~cm}^{-1}$ in the IR spectrum of HL assigned to inplane $\mathrm{OH}$ determation ${ }^{10-12}$ is shifted towards higher frequency in the spectra of the metal complex due to the formation of metal oxygen bonds. This has been further confirmed by a week bands at $1105 \mathrm{~cm}^{-1}$ corresponding to C-O-M starching ${ }^{10-12}$. Thus all of these characteristics features of the IR studies suggested the structure of the metal complex as shown in scheme.

Examination of data of the metal content in each compound revealed a 1:2 metal: ligand (M:L) stoichiometry in all of the complex of divalent metal ions and 1:3 metal : ligand stoichiometry for $\mathrm{Fe}^{3+}$ ions.

Megnetic moment $\left(\mu_{\text {eff }}\right)$ of each of the metal complex is given in Table-2. Examination of these data reveals that all complexes other than that of $\mathrm{Zn}^{2+}$ and $\mathrm{UO}_{2}{ }^{2+}$ are para magnetic while those of $\mathrm{Zn}^{2+}$ and $\mathrm{UO}_{2}{ }^{2+}$ are diamagnetic.

Table - 2 Magnetic Moment \& Reflectance Spectral data of the Metal Complexes.

\begin{tabular}{|c|c|c|c|c|}
\hline Complex & $\begin{array}{c}\text { Magnetic } \\
\text { Moment } \\
\mu_{\text {eff }}(B . . M .)\end{array}$ & $\begin{array}{c}\text { Molar } \\
\text { Conductivity } \\
\Omega \mathrm{m} \\
\mathrm{Ohm}^{-1} \mathrm{Cm}^{2} \mathrm{~mol}^{-1}\end{array}$ & $\begin{array}{l}\text { Absorption } \\
\text { band } \\
\left(\mathrm{cm}^{-1}\right)\end{array}$ & Transitions \\
\hline \multirow[t]{2}{*}{$\mathrm{Cu}-\mathrm{L}_{1}$} & 1.92 & 35.60 & 22280 & C.T. \\
\hline & & & 15635 & $2 \mathrm{~B} 1 \mathrm{~g}--->2 \mathrm{~A}_{1} \mathrm{~g}$ \\
\hline \multirow[t]{2}{*}{$\mathrm{Ni}-\mathrm{L}_{1}$} & 3.8 & 34.00 & 20534 & 3 A2g --> $3 T_{1} g(P)$ \\
\hline & & & 14680 & $3 \mathrm{~A} 1 \mathrm{~g} \mathrm{--->} 3 \mathrm{~T}_{1} \mathrm{~g}(\mathrm{~F})$ \\
\hline \multirow[t]{3}{*}{ Co $-L_{1}$} & 4.48 & 32.10 & 26760 & $4 \mathrm{~T} 1 \mathrm{~g}(\mathrm{~F}) \stackrel{--->}{4} \mathrm{~T} 2 \mathrm{~g}(\mathrm{~F})$ \\
\hline & & & 15680 & $4 \mathrm{~T} 1 \mathrm{~g}(\mathrm{~F})$---> 4 A2g \\
\hline & & & 8900 & $4 \mathrm{~T} 1 \mathrm{~g}(\mathrm{~F}) \stackrel{--->}{4} \mathrm{~T} 2 \mathrm{~g}(\mathrm{P})$ \\
\hline \multirow[t]{3}{*}{$M n-L_{1}$} & 4.9 & 34.60 & 24445 & 6 A1g ---> 4 T1g (4Eg) \\
\hline & & & 18340 & 6 A1g ---> 4 T2g (4G) \\
\hline & & & 16850 & 6 A1g $--->4$ T1g (4G) \\
\hline \multirow[t]{2}{*}{$\mathrm{Fe}-\mathrm{L}_{1}$} & 5.81 & 35.20 & 22847 & $6 \mathrm{~A} 1 \stackrel{-->}{ } 4 \mathrm{~T}_{2} \mathrm{~g}(4 \mathrm{G})$ \\
\hline & & & 18191 & 6 A1g $\stackrel{-->}{ } 4$ T1g (4G) \\
\hline
\end{tabular}

$\mathrm{Zn}^{2+}$ Diamagnetic in Nature. 
Table 3. Antifungal Activity of Ligand $\mathrm{HL}_{1}$ and its metal complexes

\begin{tabular}{cccccccc}
\hline & \multicolumn{7}{c}{ Zone of inhibition of fungus at 1000 ppm (\%) } \\
\cline { 2 - 7 } Sample & $\begin{array}{l}\text { Botrydepladia } \\
\text { thiobromine }\end{array}$ & Nigrospora Sp. $\begin{array}{l}\text { Rhizopus } \\
\text { Nigricans }\end{array}$ & $\begin{array}{l}\text { Asperginus } \\
\text { niger }\end{array}$ & $\begin{array}{l}\text { Aeprogines } \\
\text { funigalus }\end{array}$ & $\begin{array}{l}\text { andida } \\
\text { Albicans }\end{array}$ & $\begin{array}{c}\text { Andida kruseigos } \\
\text { candida grabrataHO5 }\end{array}$ \\
\hline (HL1) $-\mathrm{Mn}^{2+}$ & 67 & 70 & 72 & 73 & 71 & 69 & 68 \\
$(\mathrm{HL} 1)-\mathrm{Co}^{2+}$ & 70 & 74 & 76 & 77 & 75 & 73 & 72 \\
$(\mathrm{HL} 1)-\mathrm{Ni}^{2+}$ & 71 & 75 & 77 & 78 & 76 & 74 & 73 \\
$(\mathrm{HL} 1)-\mathrm{Cu}^{2+}$ & 73 & 76 & 78 & 80 & 77 & 75 & 74 \\
$(\mathrm{HL} 1)-\mathrm{Fe}^{3+}$ & 72 & 73 & 75 & 76 & 74 & 72 & 71 \\
$(\mathrm{HL} 1)-\mathrm{Zn}^{2+}$ & 69 & 72 & 74 & 75 & 73 & 71 & 70 \\
$(\mathrm{HL} 1)-\mathrm{UO}_{2}{ }^{2+}$ & 68 & 71 & 73 & 74 & 72 & 70 & 69 \\
$\mathrm{HL1}$ & 59 & 62 & 64 & 65 & 63 & 61 & 60 \\
\hline
\end{tabular}


The diffuse electronic spectrum of the $\left[\mathrm{Cu} \mathrm{HL}\left(\mathrm{H}_{2} \mathrm{O}\right)_{2}\right]$ metal complex shows broad bands at 15870 and $24690 \mathrm{~cm}^{-1}$ due to the ${ }^{2} \mathrm{~T} \rightarrow{ }^{2} \mathrm{~T}_{2 \mathrm{~g}}$ transition and charge transfer, respectively suggesting a distorted octahedral structure ${ }^{13-15}$ for the $\left[\mathrm{CuHL}\left(\mathrm{H}_{2} \mathrm{O}\right)_{2}\right]$ complex. Which is further confirmed by the higher value of $\mu_{\text {eff }}$ of the $\left[\mathrm{CuHL}\left(\mathrm{H}_{2} \mathrm{O}\right)_{2}\right]$ complex. The [NiHL $\left.\left(\mathrm{H}_{2} \mathrm{O}\right)_{2}\right]$ and [CuHL $\left(\mathrm{H}_{2} \mathrm{O}\right)_{2}$ ] complex gave two absorption bands respectively at 15601,22995 and $15381,22723 \mathrm{~cm}^{-1}$ corresponding to ${ }^{4} \mathrm{~T}_{1 \mathrm{~g}}-\rightarrow^{2} \mathrm{~T}_{1 \mathrm{~g}}$ and ${ }^{4} \mathrm{~T}_{1 \mathrm{~g}}(\mathrm{p})$ transitions. Thus absorption bands at the diffuse, reflectance spectra and the value of the magnetic moments $\left(\mu_{\text {eff }}\right)$ indicate and octahedral configuration for the $\left[\mathrm{NiHL}\left(\mathrm{H}_{2} \mathrm{O}\right)_{2}\right]$ and $[\mathrm{CuHL}$ $\left.\left(\mathrm{H}_{2} \mathrm{O}\right)_{2}\right]$ complex. The spectra of $\left[\mathrm{MnHL}\left(\mathrm{H}_{2} \mathrm{O}\right)_{2}\right]$ Shows weak bands at 15384,17651 and $22952 \mathrm{~cm}^{-1}$ assigned to the transitions ${ }^{6} \mathrm{~A}_{1 \mathrm{~g}} \rightarrow{ }^{4} \mathrm{~T}_{1 \mathrm{~g}}(4 \mathrm{G}),{ }^{6} \mathrm{~A}_{1 \mathrm{~g}} \rightarrow{ }^{4} \mathrm{~T}_{2 \mathrm{~g}}(4 \mathrm{G})$ and ${ }^{6} \mathrm{~A}_{1 \mathrm{~g}}(\mathrm{~F}) \rightarrow$ ${ }^{4} \mathrm{~T}_{1 \mathrm{~g}}$, respectively suggesting an octahedral structure for the $\left[\mathrm{Mn} \mathrm{HL}\left(\mathrm{H}_{2} \mathrm{O}\right)_{2}\right]$ chelate. The spectrum of $\mathrm{Fe}^{3+}$ complex has not been adequately characterized. The spectrum comprised the band ground $19002 \mathrm{~cm}^{-1}$ and other weak band ground $23006 \mathrm{~cm}^{-1}$. The latter has not very long tail. These may have the transitions ${ }^{6} \mathrm{~A}_{1 \mathrm{~g}} \rightarrow{ }^{4} \mathrm{~T}_{2}$ (4G) and ${ }^{6} \mathrm{~A}_{1} \rightarrow{ }^{4} \mathrm{~T}_{1}$ (4G). The high intensities of the bands suggests that they might be charge transfer in origin $\mu$ eff is found to be lower than normal range. In the absence of low temperature moments it is difficult to give any significance. As the spectrum of the $\left[\mathrm{Zn} \mathrm{HL}\left(\mathrm{H}_{2} \mathrm{O}\right)_{2}\right]$ polymer is not well resolved, it is not interpreted but it is $\mu_{\text {eff }}$ value shows that it is diamagnetic as expected.

Conductivities of all the complexes were measured in acetonitrile solvent and all the complexes were found to be electrolytic ${ }^{16}$ in nature of 1:2 type and molar conductivity values are in the range of $121-152 \mathrm{Ohm}^{-1} \mathrm{Cm}^{2} \mathrm{~mol}^{-1}$.

The antifungal activity of all the compounds measured for various plant pathogens. Inspection of the result shown in Table-3 indicates that all compounds are good toxic for fungi. Out of all the compounds copper chelates is more toxic than other. These compounds almost inhibit the fungi about $70 \%$. Hence produced metal chelates can be employed as garden fungicides. Further work in the direction is in progress.

\section{Reference}

1. Skanning J B and John B G, Polish Pat. 2004, 64835.

2. Kudo Kunji, Suzuki Masako and Ta Ka hiro S, Japan Pat. 2001, 275099.

3. Uvsal C, Nessin G and Hakki E, Acta Pharamacetical, 2002, 52, 1-8.

4. Meric K, Nesrin G, Hakki E, Meral O and Melike E, Farmaco. 2002, 57, 535.

5. Gents M B, Nielsen S T and Morfenym G A, Chemospheve, 2005, 61, 74.

6. Verma R S, J.Ind. Chem. Soc. 2004, 81, 627.

7. Radjohn N, Org. Synthesis, Coll.Vol. IV Wiliey \& Sons N.Y, 1963.

8. Vogel A I, Textbook of Quantitative Chemical Analysis, ELBS $5^{\text {th }}$ Edn. London, 1996.

9. Baily W R and Scott E G, Diagnostic Microbiology, The C. V. Moshy Co. St. Lovis 1966, 257.

10. Silverstein R M, Spectrometric Identification of organic compounds, $5^{\text {th }}$ Ed. John Wiley, 1991.

11. Kemp W, Orgnatic Spectroscopy, ELBS. (Macmillan’ UK), 1998.

12. Nakamoto K, Infared Spectra of Inorganic and Co-Ordination Compound, Wiley N Y, 1970.

13. ABP Lever, Inorganic Electronic Spectroscopy, Elseviv NY, 1968.

14. Figgis B N, Introduction to Ligands Field,Wiley Estern Ltd. NY, 1976.

15. Carlin R N and Van Dryneveldt A J, Magnetic Properties of Transition Metal Compound, Springe - Verlag, NY .1997.

16. Kettle F A, Coordination Compounds, Thomas Nelson \& Sons 1975. 


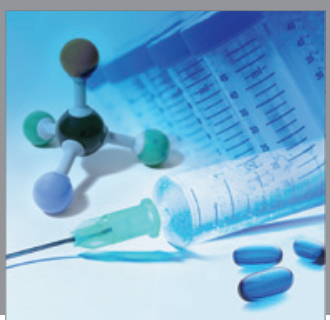

International Journal of

Medicinal Chemistry

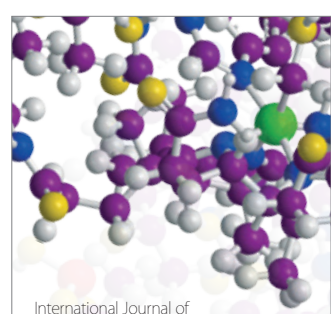

Carbohydrate Chemistry

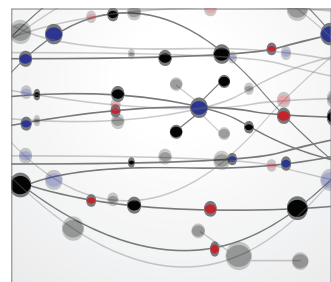

The Scientific World Journal
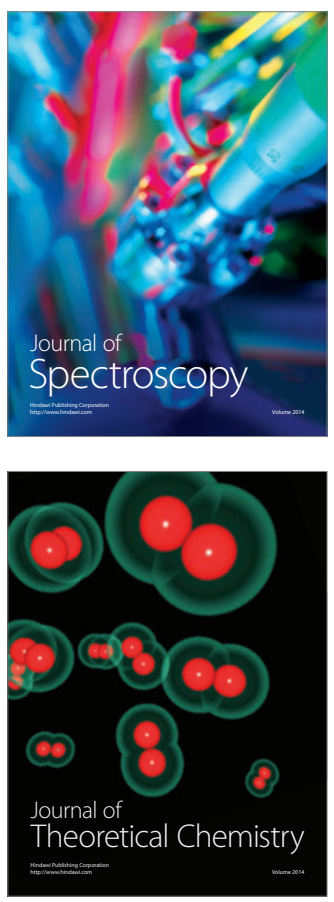
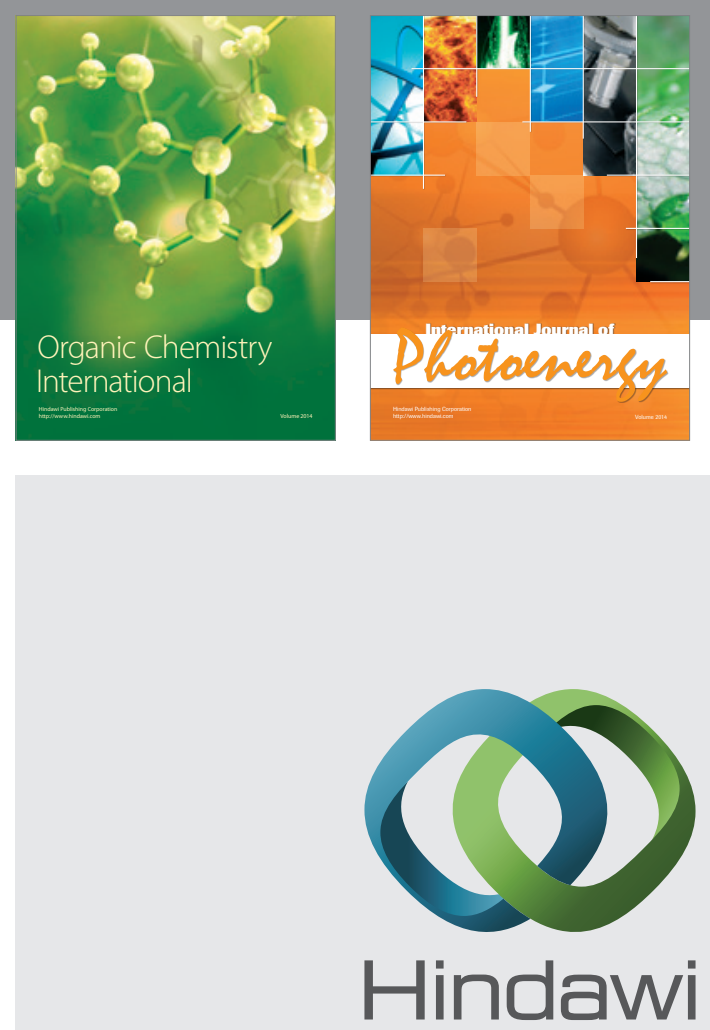

Submit your manuscripts at

http://www.hindawi.com
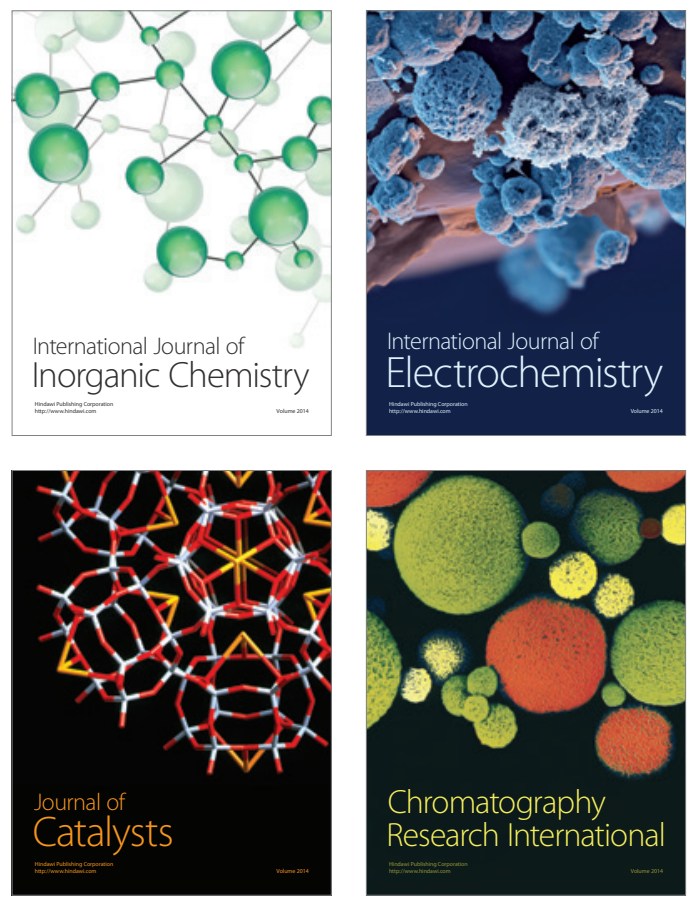
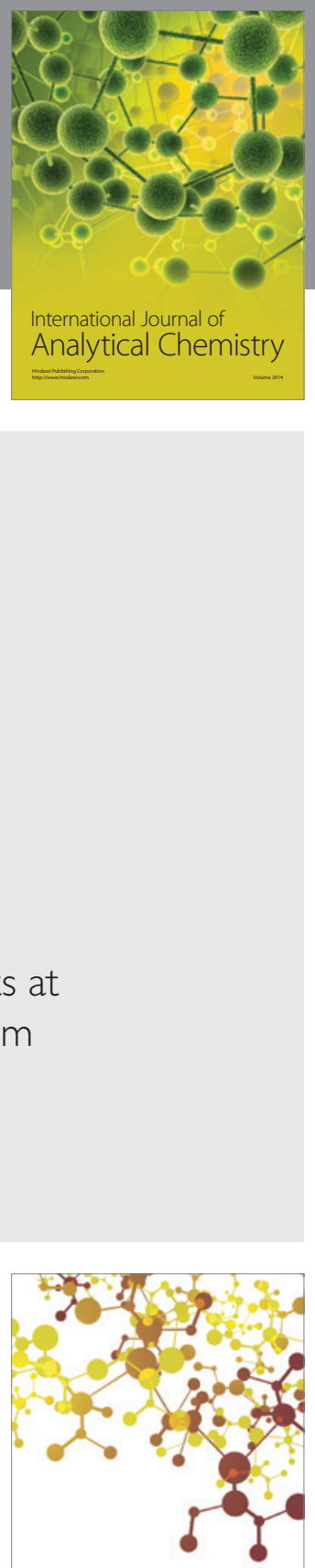

Journal of

Applied Chemistry
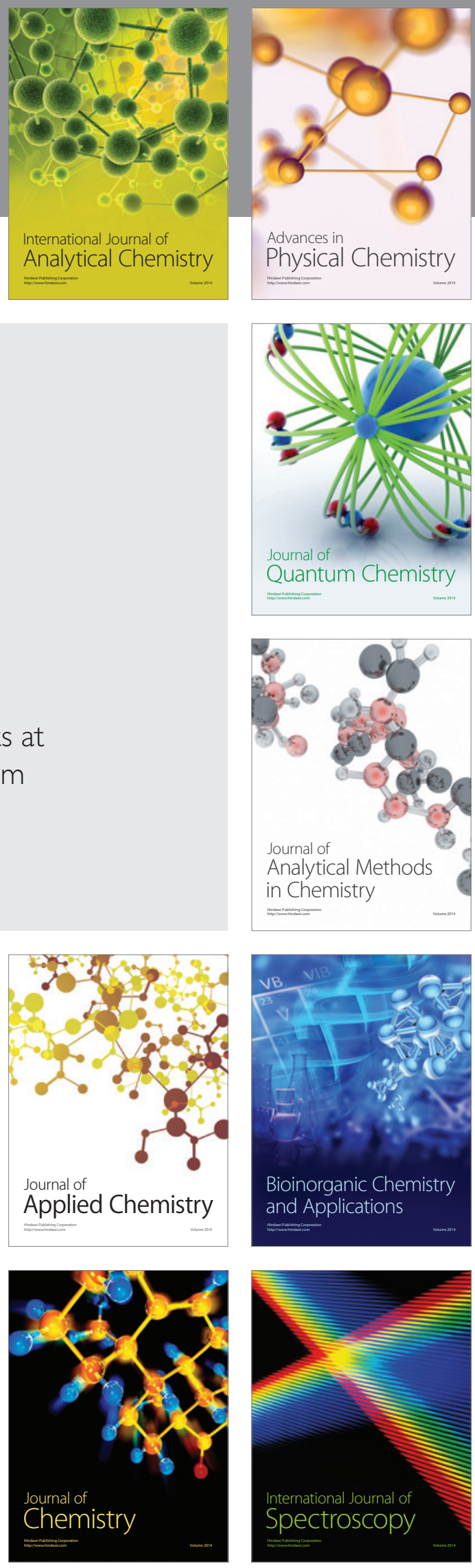